\title{
Perception of risk factors for cancer in the ABC population
}

\author{
(iD) Karine Corcione Turke ${ }^{1}$ \\ (D) Juliana Seidler Canonaco ${ }^{1}$ \\ (iD) Thiago Artioli \\ DAline Hernandez Marquez Sarafyan ${ }^{1}$ \\ (D) Erika Toshie Aoki \\ (D) Daniel Muszkat ${ }^{1}$ \\ (D) Marcel Gutierrez ${ }^{1}$ \\ (iD) Rafaela Villegas Cortez ${ }^{1}$ \\ (D) Willian Ferreira Lima Junior ${ }^{1}$ \\ (iD) Auro del Giglio'
}

1. Centro Universitário Saúde $A B C$, Santo André - SP, Brasil,

http://dx.doi.org/10.1590/1806-9282.66.6.757

\section{SUMMARY}

OBJECTIVE: To evaluate the knowledge about risk factors for cancer in patients treated at the ABC Medical School (FMABC).

METHODS: Cross-sectional observational study conducted in 2019. The American Cancer Institute's Cancer Risk Awareness Survey questionnaire was used with 29 cancer risk factors, 14 of which were proven to cause cancer and 15 without consensus or scientific evidence of causality with cancer but that are often reminded by most of the population. Qualitative variables were described by frequency and percentage, and quantitative variables by mean and standard deviation or median and range depending on normality, assessed by the Shapiro-Wilk test. The study was conducted in accordance with the Helsinki Declaration for Research and approved by the Research Ethics Committee.

RESULTS: 191 patients were included. Median age 54 (20 to 90), 64\% female. 35.6\% reported current or previous smoking. 3.1\% consumed alcohol more than 5 drinks/week. 56\% reported sedentary lifestyle. $44 \%$ had at least 1 case of cancer in relatives up to 2 nd degree. The average of correct answers in the analyzed population was 12.83 \pm 3.06 . A weak positive correlation was observed between income and number of cases (rho $=0.177, p=0.02$ ). No relationship was observed between the number of correct answers and level of education, age, sex, marital status, race or patients with a positive family history for cancer.

CONCLUSION: The knowledge about risk factors for cancer in the $A B C$ population is low, which may contribute to the adoption of risk behaviors for the disease.

KEYWORDS: Neoplasms. Perception. Risk factors.

\section{INTRODUCTION}

Neoplasms, according to estimates by the World Health Organization (WHO), will be the biggest cause of death, overcoming coronary diseases ${ }^{1}$. Demographic and epidemiological transitions have caused an increase in cancer cases, especially in developing or underdeveloped countries².

In relation to Brasil, it is expected that there will be an increase in cancer mortality, especially in the

DATE OF SUBMISSION: 04-DeC-2019

DATE OF ACCEPTANCE: 08-Dec-2019

CORRESPONDING AUTHOR: Karine Turke

Avenida Lauro Gomes, 2000 - Vila Sacadura Cabral - Santo André

São Paulo - Brasil - 09060-870E-mail: oona.daronch@yahoo.com.br - Tel: (11) 97393-8012

E-mail: karineturke@hotmail.com 
North and Northeast regions of the country by $2030^{3}$.

There are several risk factors that cause neoplasms, which are a sum of environmental and genetic factors. Thirty-five percent of cancer deaths worldwide could be attributed to the combined effect of nine risk factors, separated into five groups: diet and physical inactivity, addictive substances (use of tobacco and alcohol), sexual and reproductive health (sexually transmitted diseases), environmental risks (air pollution, solid fuels, passive smoking) and venous contamination by hepatitis B and C viruses ${ }^{4}$.

The risk of cancer in a given population depends directly on the biological and behavioral characteristics of the individuals that compose it, as well as on the social, environmental, political and economic conditions that surround them. This understanding is essential in defining investments in risk assessment research and in effective prevention actions ${ }^{5}$.

Even if we consider that the knowledge of the causal mechanism of different types of cancer is not complete, in practice, from the point of view of public health, the identification of only one component may be sufficient for major advances in prevention, based on the choice of preventive measures. Primary prevention, with an emphasis on factors associated with lifestyle at all ages and with interventions to fight environmental and occupational cancer agents, can bring good results in reducing cancer ${ }^{5}$.

Thus, it is essential that the population knows the risk factors for the development of cancer in order to prevent them in primary care, thus avoiding spending on tertiary services. This study aims to assess the perception of risk factors for neoplastic diseases in patients treated at a specialty clinic at FMABC.

\section{METHODS}

Descriptive, cross-sectional and observational study, in which the perception of the population in the $\mathrm{ABC}$ region about the risk factors for neoplasms was evaluated.

The evaluation was carried out by means of a questionnaire to be answered by the patients who visit the outpatient care of clinical and surgical specialties at the ABC Medical School.

The inclusion criteria were signing the Informed Consent Form (ICF) and being a patient at the FMABC specialty outpatient clinics. The exclusion criterion was being under 18 years old.

In the questionnaire, epidemiological and demographic factors of the patient were addressed, such as age, sex, race, marital status. Patients' habits were evaluated: use of alcohol, smoking and illicit drugs; practice of physical activity; hours of sleep a day.

We also assessed personal and family history of neoplasms. Finally, we analyzed socioeconomic data, such as average family income in minimum wages.

To assess knowledge about risk factors, patients were asked whether or not the factor addressed is a risk factor for the development of cancer. The factors were selected based on the "American Institute for Cancer Research's 2015 Cancer Risk Awareness Survey Report"6.

In addition, the perception of cancer as a disease was assessed using a questionnaire based on the Health Information National Trends Survey (Hints), which asks about the patients' perception of survival rates; pessimism in the face of the disease; the possibility of reducing the risk of the disease and the individual risk of developing cancer ${ }^{7-9}$.

The collected data were tabulated and later submitted to statistical analysis.

Categorical variables were analyzed using frequency and percentages. For continuous variables, the description was made by mean or median, depending on the data distribution.

The Shapiro-Wilk test was performed to determine the parametric distribution or not of the data. For continuous data with normal distribution, we used the Pearson correlation test. For continuous non-parametric distribution data, we used the Spearman correlation test.

For qualitative data, the Fisher or Chi-2 test was used, depending on the sample size. Continuous data with qualitative outcome were assessed by the T test, for normal distribution data, and the Mann-Whitney test for non-normal distribution data.

\section{RESULTS}

191 patients were included. Epidemiological data are described in Table 1. Most patients were female (63\%), married (54\%), white (57\%) and had completed high school (35\%). The median age was 54 years, ranging from 20 to 90 years. The median income was BRL $2,500.00$.

Regarding habits, 35\% were smokers or former smokers, $13 \%$ drank at least once a week and 56\% were sedentary. 
Regarding the personal history of cancer, $12 \%$ had already had cancer, the most common being skin cancer $(43 \%)$.

Regarding the questionnaire score, out of a total of 29 possible points, the median of correct answers was 13. A weak positive correlation was observed between income and number of correct answers ( $r h o=0.177$, $p=0.02$ ). No relationship was observed between the number of correct answers and educational level, age, sex, marital status, race or patients with a positive family history for cancer. (Table 1)

Regarding the perception of patients about risk factors for cancer, the most listed factors can be seen in Chart 1 . The factor most mentioned by the participants was smoking, with 95\%, followed by excessive exposure to sun (94\%) and use of pesticides (76\%). The least mentioned factor was asbestos (12\%). (Chart 1)

Patients' perception of the cancer itself was also analyzed (Table 2). The majority (45\%) believe that few patients remain alive after five years of diagnosis. In addition, $30 \%$ of patients agree that there is no way to effectively prevent cancer, and $65 \%$ believe that there are many recommendations for prevention and it is difficult to choose which ones to follow.

Thirty-seven percent disagree that cancer is caused primarily by lifestyle. Fifty-eight percent link cancer to death, and the majority (25\%) believe they have more than a $50 \%$ chance of developing cancer in the future.

\section{CHART 1.PATIENTS' PERCEPTION OF CANCER RISK FACTORS (RANKING)}

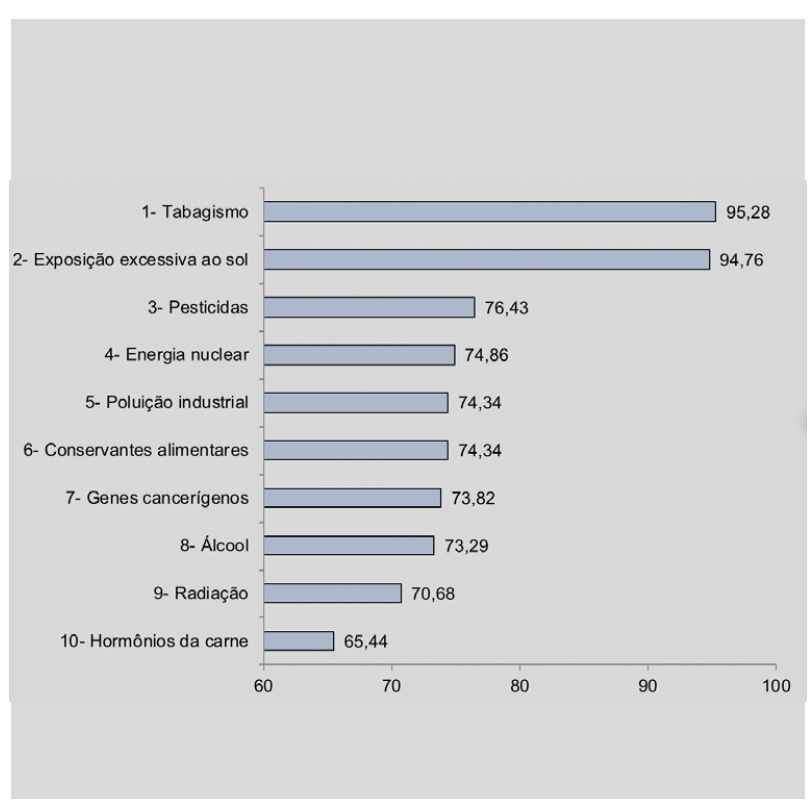

TABLE 1.EPIDEMIOLOGICAL, SOCIOECONOMIC AND HISTORY DATA FOR NEOPLASMS

\begin{tabular}{|c|c|c|}
\hline Variable & $\mathrm{N}$ & $\%$ \\
\hline Sex & 191 & \\
\hline Male & 69 & 36.12 \\
\hline Female & 122 & 63.87 \\
\hline Marital Status & \multicolumn{2}{|l|}{191} \\
\hline Married & 105 & 54.97 \\
\hline Single & 56 & 29.31 \\
\hline Divorced & 15 & 7.85 \\
\hline Widow(er) & 15 & 7.85 \\
\hline Race & \multicolumn{2}{|l|}{190} \\
\hline White & 109 & 57.36 \\
\hline Black & 19 & 10 \\
\hline Brown & 57 & 30 \\
\hline Yellow & 5 & 2.63 \\
\hline Education & \multicolumn{2}{|l|}{191} \\
\hline Illiterate & 5 & 2.61 \\
\hline Primary Education Uncompleted & 44 & 23.03 \\
\hline Primary Education Completed & 24 & 12.56 \\
\hline $\begin{array}{l}\text { Secondary Education Uncom- } \\
\text { pleted }\end{array}$ & 10 & 5.23 \\
\hline Secondary Education Completed & 67 & 35.07 \\
\hline College Education Uncompleted & 7 & 3.66 \\
\hline College Education Completed & 34 & 17.8 \\
\hline Drinking Habit & \multicolumn{2}{|l|}{191} \\
\hline Yes & 25 & 13.08 \\
\hline No & 166 & 86.91 \\
\hline Smoking & \multicolumn{2}{|l|}{191} \\
\hline Yes & 23 & 12.04 \\
\hline No & 123 & 64.39 \\
\hline Former Smoker & 45 & 23.56 \\
\hline Use of Illegal Drugs & \multicolumn{2}{|l|}{191} \\
\hline Yes & 1 & 0.52 \\
\hline No & 190 & 99.47 \\
\hline Physical Activity & \multicolumn{2}{|l|}{191} \\
\hline Yes & 83 & 43.45 \\
\hline No & 108 & 56.54 \\
\hline Had cancer & \multicolumn{2}{|l|}{191} \\
\hline Yes & 23 & 12.04 \\
\hline No & 168 & 87.95 \\
\hline Types of cancer & \multicolumn{2}{|l|}{23} \\
\hline Skin & 10 & 43.47 \\
\hline Lymphoma & 3 & 13.04 \\
\hline Breast & 2 & 8.69 \\
\hline Prostate & 2 & 8.69 \\
\hline Others & 6 & 26.08 \\
\hline History of cancer in the family & \multicolumn{2}{|l|}{191} \\
\hline Yes & 84 & 43.97 \\
\hline No & 107 & 56.02 \\
\hline Variable & $N$ & $\begin{array}{l}\text { Median and percen- } \\
\text { tiles (25-75) }\end{array}$ \\
\hline Age & 191 & $54(39-63)$ \\
\hline Income & 170 & $2,500(1,500-4,000)$ \\
\hline Final score & 191 & $13(11-15)$ \\
\hline
\end{tabular}


TABLE 2. PATIENTS' PERCEPTION OF CANCER (HINTS QUESTIONNAIRE)

\begin{tabular}{|c|c|c|}
\hline Questionnaire questions & N & $\%$ \\
\hline \multicolumn{3}{|c|}{ Number of people who develop cancer and stay alive after five years } \\
\hline Few & 87 & 45.54 \\
\hline Half & 43 & 22.51 \\
\hline Many & 42 & 21.98 \\
\hline Most & 7 & 3.66 \\
\hline Don't know & 12 & 6.28 \\
\hline \multicolumn{3}{|c|}{$\begin{array}{l}\text { There are many different recommendations on how to prevent } \\
\text { cancer. It is hard to know which of them I should chose }\end{array}$} \\
\hline Agrees & 126 & 65.96 \\
\hline Disagrees & 41 & 21.46 \\
\hline Don't know & 24 & 12.56 \\
\hline \multicolumn{3}{|c|}{$\begin{array}{l}\text { There is not much I can do to reduce the chances of developing } \\
\text { cancer }\end{array}$} \\
\hline Agrees & 58 & 30.36 \\
\hline Disagrees & 118 & 61.78 \\
\hline Don't know & 15 & 7.85 \\
\hline \multicolumn{3}{|c|}{ It seems that everything causes cancer } \\
\hline Agrees & 76 & 39.79 \\
\hline Disagrees & 105 & 54.97 \\
\hline Don't know & 10 & 5.23 \\
\hline \multicolumn{3}{|c|}{ Cancer is a disease that, when detected early, can be cured } \\
\hline Agrees & 180 & 94.24 \\
\hline Disagrees & 8 & 4.18 \\
\hline Don't know & 3 & 1.57 \\
\hline \multicolumn{3}{|c|}{ Someone can say they think they have cancer before it is diagnosed } \\
\hline Agrees & 52 & 27.22 \\
\hline Disagrees & 133 & 69.15 \\
\hline Don't know & 6 & 3.14 \\
\hline \multicolumn{3}{|c|}{$\begin{array}{l}\text { If I do regular exams to check if I have cancer, I can identify cancer } \\
\text { when it is easier to treat }\end{array}$} \\
\hline Agrees & 182 & 95.28 \\
\hline Disagrees & 4 & 2.09 \\
\hline Don't know & 5 & 2.61 \\
\hline \multicolumn{3}{|c|}{ Cancer is mainly caused by a person's behavior or lifestyle } \\
\hline Agrees & 103 & 53.92 \\
\hline Disagrees & 71 & 37.17 \\
\hline Don't know & 17 & 8.9 \\
\hline \multicolumn{3}{|c|}{ When I think of cancer, I automatically think of death } \\
\hline Agrees & 111 & 58.11 \\
\hline Disagrees & 76 & 39.79 \\
\hline Don't know & 4 & 2.09 \\
\hline \multicolumn{3}{|c|}{ What are the chances of you developing cancer in the future? } \\
\hline Very low $(0-25 \%)$ & 46 & 24.08 \\
\hline Low $(25-50 \%)$ & 37 & 19.37 \\
\hline Medium (50-75\%) & 48 & 25.13 \\
\hline High (75-99\%) & 20 & 10.47 \\
\hline Very high (100\%) & 3 & 1.57 \\
\hline Don't know & 37 & 19.37 \\
\hline
\end{tabular}

\section{DISCUSSION}

Oncological diseases represent an important and growing cause of mortality in the world. Knowledge of risk factors for cancer is essential, as it allows the population to understand situations that can prevent new cases of this disease. This study evaluated the perception of risk factors for cancer in a representative sample of the population in the $\mathrm{ABC}$ region, in order to explore associations between demographic, socioeconomic data, family history of cancer and perception of cancer risk.

Several factors have already been established in relation to cancer risk, such as alcohol, obesity, lack of physical activity, diets low in vegetables and fruits, and diets rich in red meat. However, the population is increasingly concerned with factors over which they do not have direct control or which have an uncertain relationship with cancer, such as food additives and pesticide residues ${ }^{6}$.

The American Institute for Cancer Research (AICR) continuous update project shows that a healthy life can decrease the incidence of cancer in up to - of the cases $^{6}$. The only factors correctly identified by a large part of the population are tobacco and excessive exposure to the sun.

It was possible to observe in our study that there was a positive correlation between income and correct answers in the questionnaire for the perception of risk factors. This finding corroborates data in the literature that justify that individuals of higher socioeconomic level have greater access to information and greater access to some level of study. As a result, individuals with a higher income were more aware of the behavioral risk factors for cancer and also more aware of the behavioral protective factors against cancer ${ }^{10}$.

When assessing the perception of cancer as a disease, the Hints questionnaire (Health Information National Trends Survey) was used. This questionnaire was created by the National Cancer Institute of the United States in order to fill the gap on information related to cancer and facilitate communication with the American population. By creating a cyclic population survey, which is repeated every two years, it is expected to assess the progress of health communication in terms of knowledge, attitudes and behaviors of the public studied in relation to cancer (REF).

In our study, a pessimistic attitude towards the disease was observed, since the majority said that few patients remain alive after five years of diagnosis and $58 \%$ see the disease as death. 
In addition, ways of preventing cancer should be clarified in this population, as $30 \%$ of patients agree that they cannot effectively prevent cancer, and $65 \%$ believe that there are many recommendations for prevention and it is difficult to choose which to follow. In addition, 37\% disagree that cancer is caused mainly by lifestyle, when in fact cancer is caused by genetic factors in only $5 \%$ to $10 \%$ of $\operatorname{cases}^{11,12}$.
This is a cross-sectional and observational study, so cause and consequence relationships cannot be established.

\section{CONCLUSIONS}

Knowledge about risk factors for cancer in the population in $A B C$ is low, which can contribute to the adoption of risk behaviors for the disease.

\section{RESUMO}

OBJETIVO: Avaliar o conhecimento sobre fatores de risco para câncer em pacientes atendidos nos ambulatórios da Faculdade de Medicina do $A B C(F M A B C)$.

MÉTODOS: Estudo transversal e observacional conduzido em 2019. Foi utilizado o questionário Cancer Risk Awarness Survey do American Institute for Cancer Research com 29 fatores de risco para câncer, sendo 14 fatores comprovadamente causadores de câncer e 15 sem consenso ou evidência científica de causalidade com o câncer, mas que são frequentemente citados pela população. Variáveis qualitativas foram descritas por frequência e porcentagem, e variáveis quantitativas por média e desvio padrão ou mediana e intervalo a depender da normalidade, avaliada pelo teste de Shapiro-Wilk. Estudo realizado de acordo com a Declaração de Helsinque para pesquisa e aprovado pelo Comitê de Ética em Pesquisa.

RESULTADOS: Foram incluídos 191 pacientes. Mediana de idade 54 (20 a 90), 64\% do sexo feminino; 35,6\% reportaram tabagismo atual ou anterior; $3,1 \%$ consumiam mais que cinco doses de álcool por semana; $56 \%$ reportaram sedentarismo; $44 \%$ tinham pelo menos um caso de câncer em parentes de até segundo grau. A média de acertos na população analisada foi 12,83 $\pm 3,06$. Foi observada correlação positiva fraca entre renda e número de acertos ( $r h o=0,177, p=0,02)$. Não foram observadas relações entre o número de acertos e nível de escolaridade, idade, sexo, estado civil, cor ou pacientes com história familiar positiva para câncer.

CONCLUSÃO: O conhecimento sobre fatores de risco para câncer na população do ABC é baixo, o que pode contribuir para a adoção de comportamentos de risco para a doença.

PALAVRAS-CHAVE: Neoplasias. Percepção. Fatores de risco.

\section{REFERENCES}

1. World Health Organization. Global health observatory data repository. 2011 Number of deaths (World) by cause. [cites 2019 Jun 26]. Available from: http://apps.who.int/gho/data/node.main.CODWORLD?lang=en.

2. Bray F. Transitions in human development and the global cancer burden. In: Wild CP, Stewart B, eds. World cancer report 2014. Lyon: International Agency for Research on Cancer; 2014.

3. Barbosa IR, Souza DL, Bernal MM, Costa ICC. Cancer mortality in Brasil: temporal trends and predictions for the year 2030. Medicine (Baltimore). 2015;94(16):e746.

4. Doll R, Peto R. The causes of cancer: quantitative estimates of avoidable risks of cancer in the United States today. J Natl Cancer Inst. 1981;66(6):1191-308.

5. Ministério da Saúde. Secretaria de Atenção à Saúde, Instituto Nacional de Câncer, Coordenação de Prevenção e Vigilância. A situação do câncer no Brasil. Rio de Janeiro: INCA; 2006.

6. American Institute for Cancer Research. AICR 2015 cancer awareness survey report. [cited 2019 Jul 5]. Available from: www.aicr.org

7. Cantor D, Coa K, Crystal-Mansour S, Davis T, Dipko S, Sigman R. Health
Information National Trends Survey (HINTS) 2007. Bethesda: National Cancer Institute. [cited 2019 Jul 5]. Available from: http://hints.cancer. gov/docs/HINTS2007FinalReport.pdf

8. Reddy S, Pimenta DN, Kaplan-Liss E, Guimarães MCS. Sources of Health Information in Brasil: a perspective from students of the Federal University of Rio de Janeiro. Ponto de Acesso. 2013;7(3):59-77.

9. Braz IFL, Gomes RAD, Azevedo MS, Alves FCM, Seabra DS, Lima FP, et al. Analysis of cancer perception by elderly people. Einstein (Sao Paulo). 2018;16(2):eAO4155.

10. Peretti-Watel P, Fressard L, Bocquier A, Verger P. Perceptions of cancer risk factors and socioeconomic status. A French study. Prev Med Rep. 2016:3:171-6.

11. PDQ Cancer Genetics Editorial Board. Cancer Genetics Overview (PDQ $\left.{ }^{\circledast}\right)$ : Health Professional Version. In: PDQ Cancer Information Summaries [Internet]. Bethesda: National Cancer Institute; 2019.

12. National Cancer Institute. Genetic testing for hereditary cancer syndromes. 2013. [cited 2019 Jun 21]. Available from: www.cancer.gov/ about-cancer/causes-prevention/genetics/overview-pd1 